\title{
Grazing halos and predation on juvenile Caribbean surgeonfishes
}

\author{
Hugh Sweatman*, D. Ross Robertson \\ Smithsonian Tropical Research Institute (Balboa, Panama), Unit 0948, APO AA 34002-0948, USA
}

\begin{abstract}
In the Caribbean, recruitment of a number of fishes has been found to be low at the edges of patch reefs, intermediate in the grazed halo and highest in dense seagrass. This has been attributed in part to the activities of reef-based predators. We presented small surgeonfishes held in clear glass bottles at 4 distances up to $20 \mathrm{~m}$ from the edges of reefs and found that the rate of encounters with predators (and aggressive territorial herbivores) was high at the reef edges, but encounter rates in the halo were much lower and similar to those in the dense seagrass. The low rate of interactions even $2 \mathrm{~m}$ from the reef edge implies that reef-based predators avoid the halo also, presumably because of the risk to themselves of predation from still larger piscivores. This implies that the pattern of recruitment is due to avoidance by recruits rather than the depredations of reef-based predators. Many surgeonfishes recruiting to experimental structures in the seagrass were migrant juveniles rather than settling larvae and we suggest that the gradient in recruitment of surgeonfishes reflects proximity to preferred post-settlement habitats.
\end{abstract}

KEY WORDS: Seagrass beds - Recruitment - Coral reef fish - Habitat selection - Grazing halo Predation - Model bottle

\section{INTRODUCTION}

Seagrass beds have often been considered nursery areas for fishes (reviews by Bell \& Pollard 1989, Parrish 1989), especially in the Caribbean where juveniles of many reef fishes are found in this habitat (Ogden \& Zieman 1977. Wienstein \& Heck 1979, Robblee \& Zieman 1984, Baelde 1990). These species include butterflyfishes, which are obligate reef dwellers as adults, as well as species that as adults use both coral areas and seagrass beds to varying extents. Several reasons have been proposed for reef-associated fishes to settle initially in adjacent habitats such as seagrass beds. Seagrass beds provide adequate cover for small individuals and are often more extensive than areas of coral. This means that competent larvae are more likely to encounter seagrass areas than coral areas so settlement is more likely to be successful (Parrish 1989). Competition for food and shelter is less likely in seagrass beds

\footnotetext{
- Present address: Dept of Marine Biology, James Cook University, Townsville, Queensland 4811, Australia
}

(Parrish 1989). Predation pressure may also be reduced: Ogden \& Zieman (1977) suggested that medium-sized fishes, including medium-sized piscivores that prey on juveniles, avoided seagrass beds because they were more vulnerable to large predators there.

Caribbean patch reefs and reef fronts adjacent to seagrass beds are bordered by an area of reduced seagrass cover, the 'halo', caused by the grazing activities of sea urchins and fishes foraging out from the reef (Randall 1963, Ogden et al. 1973, Ogden \& Zieman 1977. Hay 1984), as well as by hydrodynamic factors (Ogden \& Zieman 1977). In a study of fish assemblages associated with empty Strombus gigas shells set in seagrass beds in St. Croix, U.S. Virgin Islands, Shulman (1985) found that recruitment of a number of species was lowest at the edge of a reef, intermediate in the grazed halo and highest in dense seagrass, at least to a distance of $20 \mathrm{~m}$. Shulman demonstrated by manipulation that recruitment was positively correlated with the presence of shelter provided by the seagrass immediately surrounding the Strombus shells.

This result could have been due either to differential colonisation rates or to differential survival. In support 
of the latter, Shulman (1985) tethered juvenile grunts Haemulon spp. at 2 distances from the reef edge, and found that more juveniles were taken by predators at the reef edge than $20 \mathrm{~m}$ away in dense seagrass. Shulman estimated that encounter rates with predators were at least $40 \%$ higher at the reef edge and suggested that some of the increase in recruitment at greater distances was due to higher survival because of less predation by reef-associated predators.

The technique of tethering has some potential problems when estimating natural encounter rates with predators. Tethered fishes may struggle and attract predators from greater distance than would a freeswimming fish. Here we used an alternative technique to investigate the relationship between predator encounter rate and distance from patch reefs at a different site in the Caribbean and we took estimates at 4 distances from each reef to measure the change in frequency of encounters with greater resolution than Shulman's (1985) experiment.

\section{METHODS}

Study area. The study was based at the Smithsonian Tropical Research Institute's field station at Smithsoniantupo, near la Punta de San Blas on the Caribbean coast of Panama $\left(9^{\circ} 34^{\prime} \mathrm{N}, 78^{\circ} 58^{\prime} \mathrm{W}\right)$. Robertson (1987) gives a map of the area. Most of the area between the field station, la Punta de San Blas and the barrier reefs to the north is $<10 \mathrm{~m}$ deep and covered with beds of turtle grass Thalassia testudinum and manatee grass Syringodium filiforme in varying combination.

Characteristics of patch reefs and surrounding seagrass. Observations were made at 7 sites. Following Robertson (1987), the sampling sites were: Porvenir 22 (W face), Porvenir 22 (NE face), Point 21 (ENE face), Point 23 (ENE face), Point 26 (NE face) and Point $27 \mathrm{C}$ (NE face). The edges of all the patch reefs were dominated by dead and living Agaricia spp. coral.

Information on species composition, leaf density and leaf length of seagrasses was collected at 2 of the sites [Porvenir 22 (NE face) and Point 27c (NW face); Fig. 1 in Robertson 1987]. Five samples were taken at each of 3 distances from the reef edge; $1.5,7$ and $25 \mathrm{~m}$, using a $0.2 \times 0.2 \mathrm{~m}$ quadrat. The samples at each distance were at least $5 \mathrm{~m}$ apart. All seagrass within the quadrat was cut off at the level of the sand and collected. All blades were counted and a subsample of 50 of each seagrass species was measured.

Estimating rates of encounters with predatory and territorial fishes. Encounter rate was estimated in 1 observation period at each of the 7 sites 14 to 27 June 1990 using a modification of the model bottle technique (Myrberg \& Thresher 1974). To minimise diver activity immediately prior to the observations, the sites for the model bottles were marked with small flags on the day before the observation period. Small yellow flags attached to wires were set out in lines parallel to the reef edge at each of 4 distances $(0,2,10$ and $20 \mathrm{~m})$ from the edge of the chosen patch reef. The 6 flags in each line were $5 \mathrm{~m}$ apart and the overall layout was a rectangular array $25 \times 20 \mathrm{~m}$. Small surgeonfishes, Acanthurus chirurgus (mean of 8 representative individuals $33.2 \mathrm{~mm} \mathrm{SL}$, range 30 to $38 \mathrm{~mm}$ ) and $A$. bahianus (mean of 10 representative individuals: $30.4 \mathrm{~mm}$ $\mathrm{SL}$, range 26 to $35 \mathrm{~mm}$ ), were caught in seagrass surrounding Smithsoniantupo using handnets and the anaesthetic Quinaldine. Single surgeonfishes were placed in colourless glass jars (capacity 175 to $330 \mathrm{ml}$ ) closed with fibreglass mosquito mesh ( 7 meshes $\mathrm{cm}^{-1}$ ) held by a rubber band. Six jars were deployed at each of the 4 distances immediately before each observation period, 1 jar being placed on its side about $2 \mathrm{~m}$ from each flag to minimise any effect of attraction to the flags. Where the seagrass was tall, the grass was flattened for about $30 \mathrm{~cm}$ around the jar. This made jars visible to nearby predators and allowed distinction between differences in predator occurrence and differences in cover provided by the seagrass. In the observation periods at the first 2 sites [Porvenir 22 ( $\mathrm{W}$ face), Porvenir 22 (NE face)], 3 of the jars at each distance did not contain fish. This was to check for attraction to the jar itself. In the 2 periods, there was only 1 piece of evidence for an effect: a Stegastes planifrons was seen butting an empty jar set at the edge of the reef $(0 \mathrm{~m})$. Harrington (1993) found no response to empty glass jars placed in $S$. planifrons territories. At the 5 subsequent sites, all jars contained fish.

Two observers using snorkels participated in each observation period. One observer checked the 2 lines of jars closer to the reef, while the other checked the 2 more distant lines. The observers visited each jar in turn, swimming at a steady rate and looking ahead to the limit of effective visibility ( 5 to $10 \mathrm{~m}$ ). Observation periods started between 09:05 and 10:40 h or between 15:20 and 15:40 h and lasted approximately $90 \mathrm{~min}$ (range 90 to $96 \mathrm{~min}$ ). The observer checking the lines of jars at 10 and $20 \mathrm{~m}$ from the reef edge had further to swim and greater likelihood of becoming disorientated so the mean interval between visits to the more distant jars varied among observation periods from 4.0 to $6.4 \mathrm{~min}$. The mean interval between visits to the jars at 0 and $2 \mathrm{~m}$ varied from 2.7 to $3.8 \mathrm{~min}$. We assumed that interested predators would remain close to experimental prey fishes long enough to be recorded. When fishes responded to the model bottle, the species and the time of the observation were recorded. Responses included attacks or threats from both predators and territory holders, including 
rushes towards the jar, biting at the glass and sitting with their snouts less than $25 \mathrm{~mm}$ from the jar. For territorial damselfishes and surgeonfishes, this category also included threatening by presenting flanks with fins flared. Damselfishes and groupers often continued to attack the experimental fish for several successive visits by the observer. Such cases were recorded as 1 encounter. Cases where 2 or more predators were present at once, or fish of obviously different sizes were seen on separate visits, were recorded as multiple encounters. Species that came close enough to have been definitely aware of the fish in the jars $(<1.5 \mathrm{~m})$, even if they made no obvious deviation to investigate, were recorded separately.

Species were classified as predators, herbivores or benthic carnivores on the basis of Randall's (1967) study of gut contents.

\section{RESULTS}

\section{Distribution of seagrasses around patch reefs}

The seagrass Thalassia testudinum was present at all the sample distances (Table 1). Although blade density was similar at all distances, the species provided minimal cover near to the reef edge because the blades were grazed short and differed in growth form, curling so as to lie flat on the sand (Ogden \& Zieman 1977). This meant that there was still an obvious halo with reduced cover. Blade length increased with distance from the reef edge (Table 1)

Syringodium filiforme was not present in the halo near the reef edge but dominated areas away from reefs. Its blades were also longer further from the reef edge (Table 1). Though these results were from only 2 patch reefs, they indicate the general pattern around the study reefs. With reference to the location of the model bottles, seagrasses provided little cover at 0 or $2 \mathrm{~m}$ distance, but much more at $10 \mathrm{~m}$ and beyond.

\section{Distribution of encounters with predators and territorial herbivores}

Only 3 of 16 observations of piscivores attacking or threatening experimental fishes were made away from the reef edge (Table 2). In addition, 2 jars set at the reef edge of patch reef Point $27 \mathrm{c}$ had their mesh covers removed and their occupants disappeared before all the jars had been deployed at the start of observations. We did not see the species that was responsible, though there were 2 species of snapper (Lutjanus synagris and L. apodus) and 3 species of grunt (Haemulon plumieri, $H$. flavolineatum and $H$. sciurus) nearby. What is surprising is that the fish in jars placed just $2 \mathrm{~m}$ from the reef edge, with minimal cover and in full view of predators at the reef edge, received so little attention (Table 2). In terms of predation rates, out of 36 fishes presented at the reef edge, 2 were actually taken and a further 9 were attacked or threatened by 1 or more piscivores. This gives an estimated predation rate of $30.6 \%$ in $90 \mathrm{~min}$. Only $3(2.8 \%)$ of 108 fishes placed at $\geq 2 \mathrm{~m}$ from the reef edge were attacked or threatened.

When placed at the reef edge, experimental fishes were also frequently attacked by territorial herbivores (Table 2). Of the 24 attackers, 21 were damselfishes, 2 were surgeonfishes and 1 was a parrotfish. Five of the 11 experimental fish that were attacked or threatened by predators were also harassed by 1 or more territorial herbivores. Of the remaining 25 experimental fishes, 17 were harassed by herbivores. With the possible exception of 1 Monacanthus ciliatus (see below), aggressive attacks by herbivores did not occur away from the reef edge.

On 3 occasions, experimental fishes were attacked by fishes that we classified as benthic carnivores. Two of the attackers were Halichoeres bivittatus, a ubiquitous species that is abundant at the edges of reefs and commonly found far into seagrass beds. Large adults probably eat fishes as well as invertebrates. They certainly eat

Table 1. Mean length $(\mathrm{cm})$ and density (blades $\mathrm{m}^{-1}$ ) of the 2 dominant seagrasses at 2 reefs near Punta de San Blas, Panama. $\mathrm{SE}$ based on 5 samples at each distance at each reef in parentheses

\begin{tabular}{|c|c|c|c|c|c|c|c|c|}
\hline \multirow{3}{*}{$\begin{array}{l}\text { Distance } \\
\text { (Zone) }\end{array}$} & \multicolumn{4}{|c|}{ Reef PV22 } & \multicolumn{4}{|c|}{ Reef PT27 } \\
\hline & \multicolumn{2}{|c|}{ Thalassia testudinum } & \multicolumn{2}{|c|}{ Syringodium filiforme } & \multicolumn{2}{|c|}{ Thalassia testudinum } & \multicolumn{2}{|c|}{ Syringodium filiforme } \\
\hline & Density & Length & Density & Length & Density & Length & Density & Length \\
\hline $1.5 \mathrm{~m}$ (Halo) & $\begin{array}{l}795 \\
(155.1)\end{array}$ & $\begin{array}{c}9.5 \\
(0.5)\end{array}$ & 0 & - & $\begin{array}{l}1090 \\
(41.6)\end{array}$ & $\begin{array}{c}7.3 \\
(0.6)\end{array}$ & 0 & - \\
\hline 7 m (Seagrass) & $\begin{array}{l}1255 \\
(141.1)\end{array}$ & $\begin{array}{l}11.9 \\
(0.7)\end{array}$ & $\begin{array}{l}890 \\
(248.7)\end{array}$ & $\begin{array}{l}14.7 \\
(1.4)\end{array}$ & $\begin{array}{l}1100 \\
(134.2)\end{array}$ & $\begin{array}{l}10.7 \\
(0.8)\end{array}$ & $\begin{array}{l}900 \\
(102.5)\end{array}$ & $\begin{array}{l}15.2 \\
(1.2)\end{array}$ \\
\hline $25 \mathrm{~m}$ (Seagrass) & $\begin{array}{c}730 \\
(273.7)\end{array}$ & $\begin{array}{l}16.2 \\
(1.2)\end{array}$ & $\begin{array}{l}2255 \\
(409.5)\end{array}$ & $\begin{array}{l}22.4 \\
(0.9)\end{array}$ & $\begin{array}{l}1090 \\
(138.7)\end{array}$ & $\begin{array}{l}13.8 \\
(0.8)\end{array}$ & $\begin{array}{l}1535 \\
(387.9)\end{array}$ & $\begin{array}{l}17.7 \\
(2.1)\end{array}$ \\
\hline
\end{tabular}


Table 2. Summary of encounters between experimental fishes in jars and other free-ranging fishes of 3 trophic groups at 4 distances from the reef edge. Data from all sites pooled. 'Near': fishes observed within $1.5 \mathrm{~m}$ of jars but showing no interest; sch: school of unrecorded size; unid.: unidentified

\begin{tabular}{|c|c|c|c|c|c|c|c|c|}
\hline & \multicolumn{2}{|c|}{$\begin{array}{c}0 \mathrm{~m} \\
\text { (Reef) }\end{array}$} & \multicolumn{2}{|c|}{$\underset{(\text { Halo })}{2 \mathrm{~m}}$} & \multicolumn{2}{|c|}{$\begin{array}{c}10 \mathrm{~m} \\
\text { (Seagrass) }\end{array}$} & \multicolumn{2}{|c|}{$\begin{array}{c}20 \mathrm{~m} \\
\text { (Seagrass) }\end{array}$} \\
\hline & $\begin{array}{l}\text { Attack } \\
\text { or } \\
\text { threat }\end{array}$ & Near & $\begin{array}{l}\text { Attack } \\
\text { or } \\
\text { threat }\end{array}$ & Near & $\begin{array}{l}\text { Attack } \\
\text { or } \\
\text { threat }\end{array}$ & Near & $\begin{array}{l}\text { Attack } \\
\text { or } \\
\text { threat }\end{array}$ & Near \\
\hline \multicolumn{9}{|l|}{ Piscivores } \\
\hline Muraenid (unid.) & 1 & 0 & - & - & 1 & 0 & - & - \\
\hline Synodus intermedius & - & - & 0 & 2 & - & - & - & - \\
\hline Caranx bartholomaei & $1 \mathrm{sch}$ & 1 & - & - & - & - & - & - \\
\hline Epinephelus fulvus & 1 & 0 & - & - & - & - & - & - \\
\hline E. cruentatus & 9 & 10 & - & - & - & - & - & - \\
\hline Mycteroperca bonaci & - & - & 0 & 1 & - & - & - & - \\
\hline Lutjanus apodus & 0 & $1 \mathrm{sch}$ & - & - & - & - & - & - \\
\hline L. analis & 0 & 1 & - & - & - & - & - & - \\
\hline L. synagris & - & - & - & - & 1 & 0 & - & - \\
\hline Ocyurus chrysurus & - & - & 0 & 1 & 0 & 4 & 1 & 2 \\
\hline Lutjanid (unid.) & 1 & 0 & - & - & - & - & - & - \\
\hline Subtotal & $13+$ & $13+$ & 0 & 4 & 2 & 4 & 1 & 2 \\
\hline \multicolumn{9}{|l|}{ Herbivores } \\
\hline Stegastes dorsopunicans & 3 & 0 & - & - & - & - & - & - \\
\hline S. partitus & 10 & 0 & - & - & - & - & - & - \\
\hline S. planifrons & 8 & 0 & - & - & - & - & - & - \\
\hline Microspathodon chrysurus & 0 & 1 & - & - & - & - & - & - \\
\hline Scarus (unid.) & 0 & $1 \mathrm{sch}$ & 0 & $2 \mathrm{sch}$ & - & - & 0 & $1 \mathrm{sch}$ \\
\hline S. iserti & 1 & 2 & 0 & 2 & - & - & - & - \\
\hline Sparisoma (unid.) & - & - & - & - & - & - & 0 & $2 \mathrm{sch}$ \\
\hline S. radians & - & - & - & - & 0 & 2 & 0 & 1 \\
\hline Acanthurus (unid.) & 1 & 3 & 0 & 2 & - & - & - & - \\
\hline A. bahianus & - & - & - & - & - & - & 0 & 1 \\
\hline A. chirurgus & 1 & 0 & - & - & - & - & - & - \\
\hline Subtotal & 24 & $7+$ & 0 & $6+$ & 0 & 2 & 0 & $5+$ \\
\hline \multicolumn{9}{|l|}{ Benthic carnivores } \\
\hline Holocentrus adscensionis & 0 & 1 & - & - & - & - & - & - \\
\hline Hypoplectrus nigricans & 0 & 1 & - & - & - & - & - & - \\
\hline H. puella & 0 & 3 & - & - & - & - & - & - \\
\hline Haemulon flavolineatum & 0 & $3+1 \mathrm{sch}$ & - & - & - & - & - & - \\
\hline H. plumieri & 0 & $6+3 \mathrm{sch}$ & 0 & $2+1 \mathrm{sch}$ & & - & - & - \\
\hline H. sciurus & 0 & 2 & - & - & - & - & - & - \\
\hline Halichoeres bivittatus & 0 & 5 & 0 & 7 & 2 & 13 & 0 & 10 \\
\hline H. garnotti & 0 & 1 & 0 & 1 & - & - & - & - \\
\hline H. poeyi & - & - & 0 & 4 & 0 & 4 & 0 & 1 \\
\hline Pseudupeneus maculatus & - & - & 0 & 1 & 0 & 2 & 0 & 3 \\
\hline Monacanthus ciliatus & - & - & - & - & - & - & 1 & 1 \\
\hline Subtotal & 0 & $26+$ & 0 & $16+$ & 2 & 19 & 1 & 15 \\
\hline
\end{tabular}

small, partially anaesthetised fishes (D. R. Robertson pers. obs.); that they can capture fishes as large as juvenile surgeonfishes under normal conditions needs to be established. Shulman (1985) reported that wrasses investigated tethered fishes but did not seem capable of eating them. The third attacker was a Monacanthus ciliatus which vigorously bit at a jar containing a surgeonfish $20 \mathrm{~m}$ from a reef. The small mouth of this species makes it an unlikely piscivore. Randall (1967) found that seagrass, algae and organic detritus made up $>36 \%$ of the diet of $M$. ciliatus; this attack could have been aggression towards a potential competitor

\section{DISCUSSION}

The 2 studies considered here used different fish species presented in different ways to measure predator encounter rates in different areas of the Caribbean at different times; not surprisingly, they gave different 
estimates for predator encounter rates. Of the juvenile grunts that Shulman (1985) tethered in the dense seagrass, $27 \%$ had disappeared after 60 min. No comparable figure was given for fishes tethered at the reef edge, but the rate of encounters (which includes time to disappearance) was higher by a factor of 1.4 and Shulman argues that it was probably much more. In Panama, we found a 10-fold difference in number of attacks or threats between the edge of the reef and all locations away from the reef. The rate of encounters with predators away from the reef edge was much lower than in St. Croix: less than $3 \%$ of all fishes placed away from the reef edge were seen being attacked in $90 \mathrm{~min}$. Potential predators were seen close to an additional $9.3 \%$ of fishes presented.

The divergent estimates of predator encounter rate away from the reef edge may reflect differences in predator assemblages between the studies. The species composition and structure of seagrass beds and widths of the halos clearly differed (Table 1; Table 3 in Shulman 1985). There were also differences between the techniques of presentation. The surgeonfishes in the bottles generally appeared to behave normally and swam upright in the jar. Only when threatened did they press themselves against the mesh or the bottom. If Shulman's fish struggled against their tethers, they could be expected to attract predators from a wider area than would either fishes in jars or free-swimming fishes, as the auditory systems of fishes in general are sensitive to low frequency sound (Wisby et al. 1964, Hawkins 1973). A potential disadvantage of the model bottle technique is that predators may respond to the observer. Observers concentrated at the limit of effective visibility (at least $5 \mathrm{~m}$ ahead) to minimise this While these differences probably affected the absolute level of predator encounters, we suggest that the relative levels at the reef edge, in the halo and in the dense grass should not have been affected.

Shulman (1985) found that small tethered fishes were taken much more quickly at the reef edge than in the denser seagrass, implying a higher rate of encounter with predators. The same was true in this study. It is clear that the edges of patch reefs are hostile and dangerous places for small surgeonfishes. Not only are encounters with predators much more frequent at the reef edge than in the seagrass beds, but there are more attacks by territorial herbivores too. Though the attacks by Stegastes partitus and other herbivores are not themselves fatal, they reduce the area in which small surgeonfishes can feed (Foster 1985) and make it easier for predators to capture juveniles that are distracted by having to avoid territorial herbivores. One of us (D.R.R.) has recorded Epinephelus cruentatus preying on small herbivores that were being attacked by $S$. planifrons.
The probability of witnessing a predatory encounter varies with the species of predator. Epinephelus cruentatus tended to spend some minutes attacking the fishes in jars and then watched the fish in the jar from $<1 \mathrm{~m}$ for the rest of the observation period. Encounters with other types of predator might be shorter and so less likely to be detected by the periodic checks. The 2 more distant sets of jars were checked less frequently than the nearer sets because the observer had a greater distance to swim. This might have reduced the likelihood of recording predators in the seagrass beds. This difference cannot account for the observation that no predatory activity and only 4 encounters with potential predators were seen in the halo just $2 \mathrm{~m}$ from the reef edge.

In Shulman (1985), recruitment of many species, including surgeonfishes, was lowest at the reef edge, intermediate in the halo and highest in the seagrass beds (distances $\geq 10 \mathrm{~m}$ ). Shulman concluded that the increase in recruitment away from the reef edge was due either to habitat selection by settlers favouring Strombus reefs with adjacent areas of denser seagrass cover, or to increased survival because the encounter rate with reef-based predators declined with distance from the reef, or a combination of these processes. In addition to the higher predator encounter rate, recruits would be more vulnerable to predators near the reef because of the lack of cover in the halo. Shulman's gradient in encounter rate was based on observations at 2 locations: at the reef edge and in the dense seagrass $20 \mathrm{~m}$ away. By testing at intermediate distances in our study, we found that the gradient in predator encounter rate in Panama did not conform to Shulman's gradient in recruitment, being low in the halo as well as in the more distant seagrass beds. This argues against Shulman's second mechanism and implies that selective recruitment, where fishes avoid areas with low seagrass cover, is likely to explain more of any recruitment gradient than mechanisms involving reefassociated predators. Both our study and Shulman's concerned diurnal predators; there is no comparable information on nocturnal activity of predators.

In our study area in Panama, small surgeonfishes (as well as butterflyfish Chaetodon capistratus) could be found in the seagrass beds tens of metres away from any substantial cover, suggesting that they will settle in seagrass beds without additional shelter such as corals or Strombus shells. We also found a few unpigmented settlers in daily collections from experimental corals set in the halo and in the dense seagrass (Sweatman unpubl.). The great majority of the surgeonfish recruits collected each day from these experimental corals were not settlers but pigmented juvenile Acanthurus bahianus and $A$. chirurgus. These juveniles could be seen foraging in loose schools in the dense 
seagrass and would aggregate around pieces of coral and other structures in the seagrass beds. They retreated to the coral when a large fish or a diver approached and when there were strong currents. High colonisation rates to Shulman's Strombus shell reefs (Shulman 1985) make it likely that colonists included immigrants as well as settlers. If so, recruitment rates in different zones around the reefs would reflect the habitat choices of settled juveniles as well as larval supply and predation rates. Since all the species use the seagrass for cover and some, such as the surgeonfishes, depend on the associated epiphytes for food (Shulman 1985), their distributions are likely to be related to the density, height and species composition of the seagrass beds (Martin \& Cooper 1981, Bell \& Westoby 1986a, b, Bell et al. 1987). If many recruits in St. Croix were juveniles, recruitment to Strombus reefs would be largely a reflection of the density of juveniles in the surrounding seagrass. Strombus reefs set in the halo but surrounded by patches of artificial seagrass and others set in cleared halos in the dense seagrass beds would both have been isolated to some degree from areas of dense seagrass, the main juvenile habitat, and so immigration would have been reduced. This could explain the reduced recruitment to such reefs without invoking predation.

The adaptive value of selecting areas with seagrass cover is likely to be based on predation none the less. The width of the halo is partly determined by the distance that parrotfishes and surgeonfishes are prepared to forage away from the reef; these fishes are the same size as potential predators of recruits (Ogden \& Zieman 1977). In Panama, the predators most likely to be responsible for this pattern seem to be schools of jacks: Caranx ruber, C. bartholomaei and C. hippos that patrol the edges of reefs and the intervening seagrass beds, as well as large roving serranids and snappers.

Acknowledgements. We thank Plinio Gondola for assistance in the field. The manuscript was improved by comments from L. Castell, W. Gladstone, M. Hixon, G. Jones, U. Kaly and M. Shulman. The Government of the Republic of Panama and the Kuna General Congress permitted research in San Blas. The study was supported by the Smithsonian Institution's Scholarly Studies Program, grant SS1234S912.

\section{LITERATURE CITED}

Baelde, P. (1990). Differences in the structures of fish assemblages in Thalassia testudinum beds in Guadeloupe. French West Indies, and their ecological significance. Mar. Biol. 105: 163-173

Bell, J. D., Pollard, D. A. (1989). Ecology of fish assemblages

This article was presented by C. Birkeland, Mangilao, Guam and fisheries associated with seagrasses. In: Larkum, A. W. D., McComb, A. J., Shepherd, S. (eds.) Biology of seagrasses: a treatise on the biology of seagrasses with special reference to the Australian region. Elsevier, Amsterdam, p. 565-609

Bell, J. D., Westoby, M. (1986a). Importance of local changes in leaf height and density to fish and decapods associated with seagrasses. J. exp. mar. Biol. Ecol. 104: 249-274

Bell, J. D., Westoby, M. (1986b). Variation in seagrass height and density over a wide spatial scale: effects on common fish and decapods. J. exp. mar. Biol. Ecol. 104: 275-295

Bell, J. D., Westoby, M., Steffe, A. S. (1987). Fish larvae settling in seagrass: do they discriminate between beds of different leaf density? J. exp. mar. Biol. Ecol. 111: 133-144

Foster, S. A. (1985). Group foraging by a coral reef fish: a mechanism for gaining access to defended resources. Anim. Behav. 33: 782-792

Harrington, M. E. (1993). Aggression in damselfish: adultjuvenile interactions. Copiea 1993(1): 67-74

Hawkins, A. D. (1973). The sensitivity of fish to sounds Oceanogr. mar. Biol. A. Rev. 11: 291-340

Hay, M. E. (1984). Patterns of fish and urchin grazing on Caribbean coral reefs: are previous results typical? Ecology 65: $446-454$

Martin, F. D., Cooper, M. (1981). A comparison of the fish faunas found in pure stands of two tropical Atlantic seagrasses: Thalassia testudinum and Syringodium filiforme. NE Gulf Sci. 5: 31-37

Myrberg, A. A, Thresher, R. E. (1974). Interspecific aggression and its relevance to the concept of territoriality in reef fishes. Am. Zool. 14: 81-96

Ogden, J. C., Brown, R. A., Salesky, N. (1973). Grazing by the echinoid Diadema antillarum Philippi: formation of halos around West Indian Patch reefs. Science 182: 715-717

Ogden, J. C., Zieman, J. C. (1977). Ecological aspects of coral reef-seagrass bed contacts in the Caribbean. Proc. 3rd int. coral Reef Symp. 1: 377-382

Parrish, J. D. (1989). Fish communities of interacting shallowwater habitats in tropical oceanic regions. Mar. Ecol. Prog. Ser. 58: $143-160$

Randall, J. E. (1963). An analysis of the fish populations of artificial and natural reefs in the Virgin Islands Caribb. J. Sci. 3: 31-47

Randall, J. E. (1967). Food habits of reef fishes of the West Indies. Stud. trop. Oceanogr. 5: 665-847

Robblee, M. B, Zieman, J. C. (1984). Diel variation in the fish fauna of a tropical seagrass feeding ground. Bull. mar. Sci. 34: $335-345$

Robertson, D. R. (1987). Responses of two coral reef toadfishes (Batrachoididae) to the demise of their primary prey, the sea urchin Diadema antillarum. Copeia 1987: 637-642

Shulman, M. J. (1985). Recruitment of coral reef tishes: effects of distribution of predators and shelter. Ecology 66: $1056-1066$

Wienstein, M. P., Heck, K. L. (1979). Ichthyofauna of seagrass meadows along the Caribbean coast of Panama and in the Gulf of Mexico: composition, structure and community ecology. Mar. Biol. 50: 97-107

Wisby, W. J., Richard, J. D., Nelson, D. R., Gruber, S. H. (1964). Sound perception in elasmobranchs. In: Tavolga, W. N. (ed.) Marine bio-acoustics. Pergamon Press, Oxford, p. $255-268$

Manuscript first received: February 23, 1994

Revised version accepted: May 13, 1994 